\title{
Optimal Site Selection for a Solar Power Plant in Turkey Using a Hybrid AHP-TOPSIS Method
}

\author{
Merve Akçay", Mehmet Atak \\ Gazi University, Faculty of Engineering, Department of Industrial Engineering, Ankara, TURKEY \\ "merve.0306@hotmail.com
}

Received: 08 June 2018

Accepted: 28 November 2018

DOI: $10.18466 /$ cbayarfbe. 432432

\begin{abstract}
Energy is an increasing need arising from the existence of mankind. Electricity is one of the most important secondary energy sources. Obtaining of electricity from fossil sources leads to negative consequences such as climate change and environmental pollution. In addition, fossil resources are not endless. For this reason, the importance of renewable energy sources that are sustainable and not harmful to the environment such as fossil fuels is increases for electricity generation. In this study, electricity generation with solar power is considered. There are some factors to achieve efficiency in the projects of obtaining electric energy with solar energy. One of the most important of these factors is to choose the right place. There are multiple criteria that affect the correct location selection. Multiple criteria decision making methods are suitable for site selection studies where there are many criteria. In this study, Konya, Karaman, Burdur, Antalya, Mersin, Van which are fortunate cities in Turkey in terms of sunbathing are selected as alternatives. A hybrid AHP and TOPSIS method is used to select the best alternative according to the sub-criteria determined under the economic, technical, social and geographical main criteria. Criterion weights are found by the AHP method and alternatives are ranked with the TOPSIS method. The result of the study is that Mersin is the best alternative for solar power plant and Mersin is followed by Karaman, Burdur, Konya, Van and Antalya respectively.

Keywords: Renewable Energy, Electricity, AHP, TOPSIS, Solar Power Plant, MCDM
\end{abstract}

\section{Introduction}

Energy consumption is emerged with the beginning of mankind. The need for energy is increasing day by day for reasons such as rising lifestyle, developing technology and industrialization. Energy can be used in various forms. Fossil resources such as coal, oil, natural gas, and renewable resources such as wind and sun are called primary energy sources. These resources which are available in the country can be used directly. On the other hand, these resources can be used by transforming into secondary energy sources such as heat, fuel and electricity. Electricity is an important secondary energy source that we use most of our daily life. The requirements of modern life increase the need for electricity. Many primary energy sources are used for electricity generation. A large part of the electricity production in Turkey are derived from fossil sources. However, the use of fossil resources for electricity generation has negative effects. One of the biggest negative effects is that it causes climate change. Carbon dioxide and similar greenhouse gases arising from the use of fossil fuels cause significant increases in surface temperature, which can affect the whole world, such as global warming and climate change. In addition to the negative consequences of fossil resource use such as climate change and pollution, the ending is also a big problem. Fossil resources are one day confronted with the danger of total exhaustion. Fossil fuel reserves are approaching critical levels. People are turning to new sources for electricity generation because of the increasing demand for electricity and the disadvantages of using fossil fuels. Renewable energy sources are both savior for solving these problems as they are both sustainable and do not harm the environment like fossil resources. For this reason, the importance is gradually increasing.

Renewable energy is an energy source that can be obtained from natural sources and renew itself constantly. Renewable energy is an energy that cannot be consumed because it can renew itself naturally. In addition, the use of renewable energy can be used to reduce carbon emissions that are harmful to the environment, and to reduce external dependency by using domestic energy resources.

Solar energy is one of the highest potential sources of renewable energy. Solar energy is an opportunity to meet both electricity needs by using domestic resources and to reduce external dependence and to help protect the environment and people from the negative effects of fossil resources. In addition to reducing external dependency, it will also contribute to the country economy by creating employment opportunities.

Turkey is fortunate compared to many other developed countries in terms of average sunshine time, but this 
advantage is not considered enough. Established a solar power plant in the right place in Turkey provides both economic and environmental benefits [1]. If high efficiency is taken from solar power plants, investors give more importance to this sector so new solar energy investments will increase and solar energy share is increases in electricity production.

The aim of this study is to select the most suitable city for Turkey to establish solar power plants. Most cities in Turkey are fortune in terms of sun. However, there are many criteria to establish a solar power plant other than sunshine amount. In this study, based on expert opinions and literature, firstly, the criteria for determining the location of the solar power plant are determined, then Solar Energy Potential Atlas is examined to determine the alternatives, cities which are advantageous in terms of sunshine, are chosen as alternatives. A hybrid AHPTOPSIS method is used for this study. In the first phase of the study, criteria weights are obtained by applying the AHP method by taking the scales of experts. In the last stage, alternatives are ordered by TOPSIS method and the most suitable is decided.

When the studies in recent years are examined, it is frequently seen that the multi-criteria decision making methods are used for selection of solar power plant problems.

Nehra and Lutha use AHP and TOPSIS to select best place for solar power plant in India similar to this study [3]. Lozano et al., use firstly AHP to calculate criteria weights like this study also then to rank alternatives use TOPSIS and ELECTRE TRI methods for solar power plant place selection in Spain. They aims to compare TOPSIS and ELECTRE TRI results. They find not identical but similar results [4]. Beltran et al., use AHP and ANP methods as different from TOPSIS in this study method for location selection of a solar power plant investment project in Spain [5]. Wu and Geng make study to select location for solar-wind hybrid power plant with AHP method [6]. In the study of Garni and Awasthi, the location of the solar energy plant is selected by the AHP method in Arabia [7].

There are multi criteria solar power plant site selection studies for foreign countries as shown in the literature review. This article is intended to make such an article in Turkey. Also, there are some power plant site selection studies in Turkey. In Turkey, Özdemir et al., use AHP and VIKOR methods for solar energy plant site selection in their articles [1]. They also make a solar power plant site selection among some cities in Turkey similar to this study. However, they use VIKOR method instead of TOPSIS method unlike this study and in this study alternative cities are defined according to being advantageous in terms of sunshine unlike their study. Akkaş et al., use AHP, TOPSIS, ELECTRE and VIKOR methods in their study to select city for solar power plant [2]. They use multiple multi-criteria decision methods for same site selection problem and they find Karaman. In this study a hybrid AHP-TOPSIS method. They use various multi criteria decision making methods for same site selection problem to rank alternatives. However, in this study AHP is used for finding criteria weights and only TOPSIS is used to rank alternatives.

\section{Materials and Methods}

There are many criteria that affects the result for site selection problems. Decision making becomes more difficult as the number of criteria increases. Multi criteria methods helps to make selection with multi criteria site selection problems. Comparisons and grading are performed between alternatives according to weighted criteria with multi-criteria decision making methods. Then, the best alternative site is found for the problem solution. Since this problem of location choice is suitable to use multi-criteria decision making methods, a multicriteria decision making approach consisting of a combination of AHP-TOPSIS methods is used in the study. The main criteria and sub criteria weights are determined by the AHP method, and the cities are ranked according to relevance ratings by the TOPSIS. Super Decision 2.6.0 program is used for AHP application and Microsoft Excel is used for TOPSİS.

AHP is a useful method to find criteria weights. Therefore, AHP is used for first part of study which is finding criteria weights. The AHP method is applied with making comparisons of alternatives for the criteria that influence decision. AHP method that helps decision makers to cope with multi-criteria problems. For this hybrid AHP-TOPSIS study, firstly purpose, criteria and alternatives are defined. A hierarchical structure is constructed, with the goal being the highest level, the criteria intermediate and the alternatives at the lowest level. Criteria comparison matrices are constructed and the criteria are compared among themselves in the AHP part of the study. Criteria comparison matrices are applied by General Directorate of Renewable Energy Experts according to Saaty Importance Scale. Criteria weights are found by processing the values in comparison matrices in the Super Decision Program.

TOPSIS is a suitable method to rank alternatives with using criteria weights which are found by using AHP. TOPSIS is used in the second part which is ranking alternatives of the study. TOPSIS is a method developed for making preference ordering based on the ideal solution distance. While the ideal solution brings the benefit criteria to the highest level, the negative solution reduces the cost criteria to the lowest level. According to this method, the best alternative is the nearest ideal solution and farthest negative solution [10]. For applying TOPSIS method, a decision matrix containing the features of the criterion according to the alternatives is constructed [9]. The normalized decision matrix and weighted normalized matrix are obtained. The maximum and minimum values are determined for each column of 
the weighted matrix. The distances to the maximum and minimum ideal points are calculated. Finally, relative affinity to ideal solution is calculated and alternatives are ranked according to their relative affinity to ideal solution values [12].

\subsection{Application}

Firstly, AHP is applied to find main criteria of economic, technical, geographic and social and their sub criteria weights and then TOPSIS is applied to rank alternative provinces for solar power plant establishing in Turkey.

\subsubsection{Determination of Main Criteria, Sub Criteria and Alternatives}

Table 1. Criteria and alternatives
Technical criteria are determined according to the information obtained from General Directorate of Renewable Energy. Other criteria are determined based on literature and opinions of authors. Determined economic criteria and some geographic criteria like erosion risk and earthquake risk are seen in some studies in the literature. However, some geographic criteria like rainfall amount, number of snowy days and social criteria are determined by authors. There is no relationship between criteria. Each criteria is independent of each other. Then, Solar Energy Potential Energy is examined to determine alternatives to be considered, and cities in Turkey that are advantageous in terms of sunbathing are chosen as alternatives. Criteria and alternatives are shown in table 1 .

\begin{tabular}{|c|c|c|c|c|}
\hline \multicolumn{5}{|c|}{ Selection of province for solar power plant } \\
\hline \multicolumn{5}{|c|}{ Main Criteria } \\
\hline $\begin{array}{l}\text { Economic Criteria } \\
\text { (EC) }\end{array}$ & $\begin{array}{l}\text { Technical } \\
\text { (TC) }\end{array}$ & Criteria & $\begin{array}{l}\text { Geographic Criteria } \\
\text { (GC) }\end{array}$ & $\begin{array}{l}\text { Social Criteria } \\
(\mathrm{SC})\end{array}$ \\
\hline $\begin{array}{l}\text { Transformer Tariff Area } \\
\text { (TA) } \\
\text { Regional Incentives (RI) } \\
\text { Land Costs (LC) }\end{array}$ & $\begin{array}{l}\text { Sunshine D } \\
\text { Solar Radia } \\
\text { Amount of }\end{array}$ & $\begin{array}{l}\text { ation (SD) } \\
\text { on (SR) } \\
\text { ergy (AE) }\end{array}$ & $\begin{array}{l}\text { Rainfall Amount(RA) } \\
\text { Number of snowy days (NS) } \\
\text { Earthquake Risk (ER) } \\
\text { Erosion Risk (EO) }\end{array}$ & $\begin{array}{l}\text { Unemployment (UM) } \\
\text { Workforce (WF) }\end{array}$ \\
\hline \multicolumn{5}{|l|}{ Alternatives } \\
\hline Konya & Karaman & Antalya & Burdur & Mersin \\
\hline
\end{tabular}

\subsubsection{AHP Implementation}

Step 1: Comparative matrices are created in which the main criteria are compared with each other and the subcriteria of each main criterion are compared with each other. The comparison matrices are turned into questionnaires and given to 10 specialists working in the General Directorate of Renewable Energy. Experts

Table 2. Saaty Importance Scale [8]. evaluate criteria according to Saaty Importance Scale in table 2 . The average comparison matrices are obtained by taking the geometric mean of the 10 expert's comparisons. Geometric mean of main criteria matrices, economic criteria matrices, technical criteria matrices, social criteria matrices, geographic criteria matrices are given in table 3 , table 4 , table 5 , table 6 , table 7 , respectively.

\begin{tabular}{|l|l|}
\hline $\begin{array}{l}\text { Intensity of importance } \\
\text { on an absolute scale }\end{array}$ & Definition \\
\hline 1 & Equal Importance \\
\hline 3 & Moderate importance of one over another \\
\hline 5 & Essential or strong importance \\
\hline 7 & Very strong importance \\
\hline 9 & Extreme importance \\
\hline $2,4,6,8$ & Intermediate values between the two adjacent judgements \\
\hline
\end{tabular}

Table 3. Main criteria comparison matrix.

\begin{tabular}{|l|l|l|l|l|}
\hline $\begin{array}{l}\text { Main } \\
\text { Criteria }\end{array}$ & TC & EC & GC & SC \\
\hline TC & 1 & 1,550 & 3,551 & 5,842 \\
\hline EC & 0,645 & 1 & 2,664 & 4,974 \\
\hline GC & 0,282 & 0,422 & 1 & 2,337 \\
\hline SC & 0,171 & 0,201 & 0,423 & 1 \\
\hline
\end{tabular}

Table 4. Economic criteria comparison matrix.

\begin{tabular}{|l|l|l|l|}
\hline EC & TA & RI & LC \\
\hline TA & 1 & 0,432 & 0,230 \\
\hline RI & 2,314 & 1 & 0,512 \\
\hline LC & 4,342 & 1,951 & 1 \\
\hline
\end{tabular}


Table 5. Technical criteria comparison matrix.

\begin{tabular}{|l|l|l|l|}
\hline TC & SR & SD & AE \\
\hline SR & 1 & 1,297 & 2,141 \\
\hline SD & 0,771 & 1 & 1,866 \\
\hline AE & 0,467 & 0,536 & 1 \\
\hline
\end{tabular}

Table 6. Social criteria comparison matrix.

\begin{tabular}{|l|l|l|}
\hline SC & UM & WF \\
\hline UM & 1 & 2,238 \\
\hline WF & 0,447 & 1 \\
\hline
\end{tabular}

Table 7. Geographic criteria comparison matrix.

\begin{tabular}{|l|l|l|l|l|}
\hline GC & ER & EO & RA & NS \\
\hline ER & 1 & 0,728 & 0,269 & 0,411 \\
\hline EO & 1,374 & 1 & 0,358 & 0,578 \\
\hline RS & 3,722 & 2,796 & 1 & 2,024 \\
\hline NS & 2,430 & 1,730 & 0,494 & 1 \\
\hline
\end{tabular}

Step 2: The hierarchical structure of the problem is established as shown in figure 1 . The values in the Table 8. Criterion weights.

\begin{tabular}{|l|l|l|l|l|l|l|l|l|l|l|l|}
\hline LC & RI & TA & ER & EO & NS & RA & WF & UM & AE & SR & SD \\
\hline 0,190 & 0,099 & 0.043 & 0,016 & 0,022 & 0.036 & 0,064 & 0,021 & 0,047 & 0,092 & 0,206 & 0,165 \\
\hline
\end{tabular}

\subsubsection{TOPSIS Implementation}

Criteria in a decision matrix can be expressed qualitatively or quantitatively. Therefore, there is a unit difference between the criteria. To convert the values in the decision matrix into a common expression, the scale of quantification of qualitative values in the table 9 is used [11].

Table 9. Quantification to qualitative values.

\begin{tabular}{|l|l|}
\hline Scale & Condition \\
\hline 9 & Very High \\
\hline 7 & High \\
\hline 5 & Medium \\
\hline 3 & Low \\
\hline 1 & Extra Low \\
\hline
\end{tabular}

Step 1: Data related to criterion are obtained.

Economic Criteria: Economic criteria for investment in a solar power plant are important for both the country's economy and the investor. The solar power plant established in an economically selected location provides profit by encouraging new investors to invest in this field, enabling solar power plants to become widespread and economically efficient investments within the country. 3 sub-criteria are identified for economic criteria.

Transformer Tariff Area: For electricity generation with solar power, the connection in all processes from production to consumption is provided with transformer stations. For this reason, transformer stations are an average comparison matrices are entered into the program and the weights of the criteria are found and consistency analyzes are performed. Obtained criterion weights are given in table 8 .

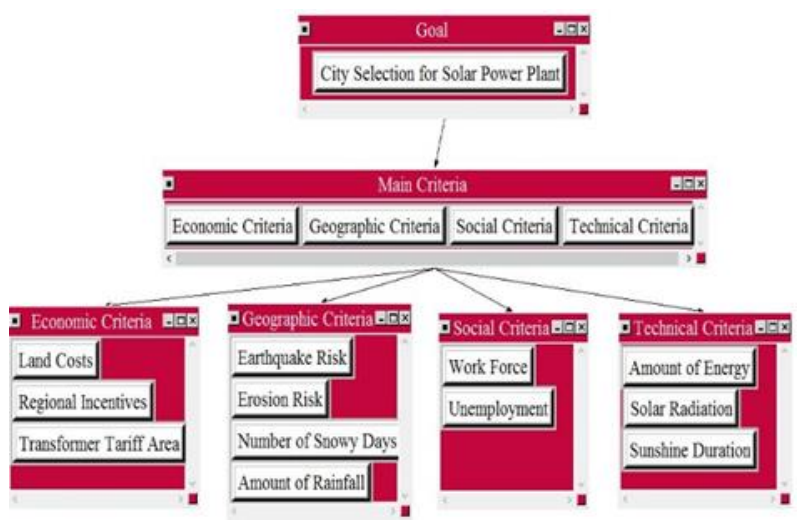

Figure 1. Hierarchical Structure. important element for solar power plants. Turkey is divided into 14 regions transformer tariff area according to usage fees. Transformer usage costs vary according to these regions. Transformer usage costs are given in the table 10.

Table 10. Transformer usage fees [13].

\begin{tabular}{|l|l|}
\hline Tariff Area & Usage Fee (Tl/Mw-Years) \\
\hline Burdur & $27.970,58$ \\
\hline Antalya & $29.392,94$ \\
\hline Karaman Konya & $32.561,70$ \\
\hline Mersin & $37.577,48$ \\
\hline Van & $46.167,30$ \\
\hline
\end{tabular}

Regional Incentives: The state provides to encourage investors according to regions to reduce the development gap between provinces and to increase the production and export potential of the provinces. Turkey is divided into 6 regions according to level of incentive. This criterion contains qualitative values as shown in table 11 Therefore, this criterion values are converted quantitative values according to table 9 .

Table 11. Regional incentives [14].

\begin{tabular}{|l|l|l|}
\hline Alternative & $\begin{array}{l}\text { Regional Incentive } \\
\text { Condition }\end{array}$ & $\begin{array}{l}\text { Numerical } \\
\text { Value }\end{array}$ \\
\hline Burdur & Medium & 5 \\
\hline Antalya & Extra Low & 1 \\
\hline Karaman & Medium & 5 \\
\hline Konya & Low & 3 \\
\hline Mersin & Medium & 5 \\
\hline Van & Very High & 9 \\
\hline
\end{tabular}


Land Costs: Land costs are an important criterion affecting the investment of solar plants economically. Low land costs provide economic advantage for solar power plant. Barren land costs of alternatives are obtained from the land cost calculation system of the Revenue Administration. Land costs of alternatives are shown in table 12 .

Table 12. Land costs [15].

\begin{tabular}{|l|l|}
\hline Alternative & $\begin{array}{l}\text { Land Cost } \\
\text { ( TL/M }{ }^{2} \text { ) }\end{array}$ \\
\hline Antalya & 0.704 \\
\hline Burdur & 0.366 \\
\hline Konya & 0.243 \\
\hline Karaman & 0.350 \\
\hline Van & 0.408 \\
\hline Mersin & 0.312 \\
\hline
\end{tabular}

Technical Criteria: There are some technical requirements that the area to install the solar power plant should provide. The area must have a solar energy value of at least 2000 hours of sunshine annually and an annual solar energy of 1,500 kWh per square meter. In addition, the number of days with a 4-hour sunshine period should not be less than 150 [16]. All of the alternatives are provided by these conditions. Sunshine duration, solar radiation and energy potential of the region to be installed for solar power plant are important criteria affecting efficiency.

Sunshine Duration: Although Turkey is a lucky country in terms of overall sun while there are still more advantageous between provinces. Therefore, the duration of sunshine is determined as a sub-criterion by technical criteria. Solar Energy Potential Atlas is used for the sunshine duration of the provinces. The daily average sunshine durations for alternatives are given table 13 .

Table 13. Sunshine durations [16].

\begin{tabular}{|l|l|}
\hline Alternative & $\begin{array}{l}\text { Daily Average Sunshine } \\
\text { Duration (Hours) }\end{array}$ \\
\hline Antalya & 8.247 \\
\hline Burdur & 8.067 \\
\hline Konya & 7.940 \\
\hline Karaman & 8.240 \\
\hline Van & 8.408 \\
\hline Mersin & 8.257 \\
\hline
\end{tabular}

Solar Radiation: High solar radiation affects the efficiency of solar power plants. Solar radiation, such as sunshine time, also varies by province. It is advantageous to choose the provinces where solar radiation is high in order to install solar plants. Solar radiation quantities of alternatives are calculated from the Solar Energy Potential Atlas and they are given in table 14.
Table 14. Solar radiation [16].

\begin{tabular}{|l|l|}
\hline Alternative & $\begin{array}{l}\text { Average Solar Radiation } \\
\text { (kW h/m } \mathbf{2} \text {-day })\end{array}$ \\
\hline Antalya & 4.511 \\
\hline Burdur & 4.471 \\
\hline Konya & 4.408 \\
\hline Karaman & 4.550 \\
\hline Van & 4.481 \\
\hline Mersin & 4.451 \\
\hline
\end{tabular}

Amount of Energy: This criterion means how much solar energy can be produced in the alternative provinces. It is an advantage that the provinces with high potential are selected for the solar plant. In Solar Energy Potential Atlas, the amount of energy that can be produced according to different substances is given but in this study the highest yield of monocrystalline solar cell is taken into consideration [16]. Amount of energy can be produced for alternatives are given in the table 15 with using monocrystalline solar cell.

Table 15. Amount of Energy [16].

\begin{tabular}{|l|l|}
\hline Alternative & $\begin{array}{l}\text { Amount Of Energy (kW } \\
\text { hours/year) }\end{array}$ \\
\hline Antalya & 27600 \\
\hline Burdur & 27500 \\
\hline Konya & 27000 \\
\hline Karaman & 28000 \\
\hline Van & 27900 \\
\hline Mersin & 27000 \\
\hline
\end{tabular}

Geographical Criteria: Turkey is a geographically rich country with different characteristics. Geographic features vary according to regions or even provinces. It is necessary to take into account the risks such as earthquakes and erosion caused by geographic features in the installation of solar plants. Earthquakes and erosion in the area where the plant is installed, can cause great damage to the power plant and may even make it unusable, so it would be useful to choose places where such risks are less. Yet climate differences also among Turkey's most important features. The amount of rainfall, the number of snowy days vary by province and may affect the solar power plants. Therefore, earthquake risk, erosion risk, rainfall and number of days are determined as sub-criteria.

Rainfall Amount: The amount of annual rainfall in the region where the solar power plant is installed should be low. Therefore, priority should be given to provinces with low rainfall. Average annual rainfall amounts of alternatives are shown in the table 16 . 
Table 16. Rainfall Amounts [17].

\begin{tabular}{|l|l|}
\hline Alternative & $\begin{array}{l}\text { Yearly Average Rainfall } \\
\text { Amount (Mm) }\end{array}$ \\
\hline Antalya & 1066.9 \\
\hline Burdur & 427.9 \\
\hline Konya & 322.4 \\
\hline Karaman & 330.8 \\
\hline Van & 388.5 \\
\hline Mersin & 592.3 \\
\hline
\end{tabular}

Number of snowy days: The fact that the number of days covered with annual snow is also a factor affecting the solar plant negatively. Therefore, alternatives which have low number of snowy days are better for solar power plant. Minimum number of snowy days of alternatives are given in table 17.

Table 17. Minimum Number of Snowy Days [17].

\begin{tabular}{|l|l|}
\hline Alternative & $\begin{array}{l}\text { Yearly } \\
\text { Numbers Of Snowy Days } \\
\text { (Days) }\end{array}$ \\
\hline Antalya & 4.04 \\
\hline Burdur & 4.04 \\
\hline Konya & 17.5 \\
\hline Karaman & 17.5 \\
\hline Van & 68.3 \\
\hline Mersin & 4.04 \\
\hline
\end{tabular}

Earthquake Risk: Turkey is divided into five earthquake zone. According to provinces, earthquake risk varies. Establishment of the installed solar plant in cities with less risk reduces the risk of damage and unavailability. Turkey Earthquake Risk Map is examined, alternatives are determined in which earthquake zone. However, this criteria have qualitative values, so quantification scale in table 9 is used. Earthquake scores of alternatives are given in table 18 .

Table 18. Earthquake Zones [18].

\begin{tabular}{|l|l|l|}
\hline Alternative & $\begin{array}{l}\text { Earthquake } \\
\text { Zone }\end{array}$ & $\begin{array}{l}\text { Numerical } \\
\text { Value }\end{array}$ \\
\hline Burdur & Very High & 9 \\
\hline Antalya & High & 7 \\
\hline Karaman & Extra Low & 1 \\
\hline Konya & Low & 3 \\
\hline Mersin & Medium & 5 \\
\hline Van & High & 7 \\
\hline
\end{tabular}

Erosion Risk: Erosion is a major problem in Turkey. Erosion is observed in most of our lands. One of the main reasons of erosion is human impact. Destruction of vegetation leads to erosion. Solar power plants can also damage the soil. For this reason, the establishment of provinces with a lower risk of erosion may prevent the damage to the country from geographic point of view. Also, erosion risk criterion has qualitative values, so they are converted to numerical value with quantification scale. Erosion risk scores are given in table 19.

Table 19. Erosion Risk [19].

\begin{tabular}{|l|l|l|}
\hline Alternative & $\begin{array}{l}\text { Erosion } \\
\text { Condition }\end{array}$ & $\begin{array}{l}\text { Numerical } \\
\text { Value }\end{array}$ \\
\hline Burdur & Low & 3 \\
\hline Antalya & Medium & 5 \\
\hline Karaman & High & 7 \\
\hline Konya & High & 7 \\
\hline Mersin & Medium & 5 \\
\hline Van & High & 7 \\
\hline
\end{tabular}

Social Criteria: Unemployment and workforce are important social issues for a country. The facilities established in the country provide jobs to people. Solar power plants also create jobs in the provinces where they are established.

Unemployment: Unemployment varies according to the province in Turkey. Solar power plants established in provinces with high unemployment provide social benefits to the country by creating employment. Turkey is divided into 26 regions, according to the workforce and unemployment situation. Unemployment rates are given in table 20.

Table 20. Unemployment Rates [20].

\begin{tabular}{|l|l|}
\hline Alternative & Unemployment Rate (\%) \\
\hline Antalya & 11.6 \\
\hline Burdur & 11.6 \\
\hline Konya & 6.1 \\
\hline Karaman & 6.1 \\
\hline Van & 9.2 \\
\hline Mersin & 10.4 \\
\hline
\end{tabular}

Workforce: The absence of staff to work in the installed facilities or the limited number of staff is considered to have a negative impact. For this reason, it is more logical to make this investment when the workforce potential is high. Workforce rates are given Table 21.

Table 21. Workforce Rates [20].

\begin{tabular}{|l|l|}
\hline Alternative & Workforce Rate (\%) \\
\hline Antalya & 4.2 \\
\hline Burdur & 4.2 \\
\hline Konya & 2.8 \\
\hline Karaman & 2.8 \\
\hline Van & 1.9 \\
\hline Mersin & 4.8 \\
\hline
\end{tabular}

Step 2: TOPSIS decision matrix is established and it is given in table 22 . 
Table 22. TOPSIS decision matrix.

\begin{tabular}{|l|c|c|c|c|c|c|c|c|c|c|c|c|}
\hline & GS & GR & ÜE & ARM & BT & TTB & DP & ERZ & YM & KG & IŞS & IŞG \\
\hline Burdur & 8,067 & 4,471 & 27500 & 0,366 & 5 & 27,97 & 9 & 3 & 427,9 & 4,04 & 11,6 & 4,2 \\
\hline Antalya & 8,247 & 4,511 & 27600 & 0,704 & 1 & 29,392 & 7 & 5 & 1066,9 & 4,04 & 11,6 & 4,2 \\
\hline Karaman & 8,240 & 4,55 & 28000 & 0,35 & 5 & 32,561 & 1 & 7 & 330,8 & 17,5 & 6,1 & 2,8 \\
\hline Konya & 7,940 & 4,408 & 27000 & 0,243 & 3 & 32,561 & 3 & 7 & 322,4 & 17,5 & 6,1 & 2,8 \\
\hline Mersin & 8,257 & 4,451 & 27000 & 0,312 & 5 & 37,577 & 5 & 5 & 592,3 & 4,04 & 10,4 & 4,8 \\
\hline Van & 8,408 & 4,481 & 27900 & 0,408 & 9 & 46,167 & 7 & 7 & 388,5 & 68,3 & 9,2 & 1,9 \\
\hline Weights & 0,165 & 0,206 & 0,092 & 0,19 & 0,099 & 0,043 & 0,016 & 0,022 & 0,064 & 0,036 & 0,047 & 0,021 \\
\hline
\end{tabular}

Step 3: The decision matrix is normalized and criterion weights are processed to obtain the weighted normalized matrix as shown in table 23 .

Table 23. Weighted normalized matrix.

\begin{tabular}{|l|l|l|l|l|l|l|l|l|l|l|l|l|}
\hline & GS & GR & ÜE & ARM & BT & TTB & DP & ERZ & YM & KG & ISSS & IŞG \\
\hline Burdur & 0,066 & 0,084 & 0,038 & 0,067 & 0,038 & 0,014 & 0,010 & 0,005 & 0,019 & 0,002 & 0,024 & 0,010 \\
\hline Antalya & 0,068 & 0,085 & 0,038 & 0,129 & 0,008 & 0,015 & 0,008 & 0,008 & 0,048 & 0,002 & 0,024 & 0,010 \\
\hline Karaman & 0,068 & 0,085 & 0,038 & 0,064 & 0,038 & 0,016 & 0,001 & 0,011 & 0,015 & 0,009 & 0,012 & 0,007 \\
\hline Konya & 0,065 & 0,083 & 0,037 & 0,045 & 0,023 & 0,016 & 0,003 & 0,011 & 0,014 & 0,009 & 0,012 & 0,007 \\
\hline Mersin & 0,068 & 0,084 & 0,037 & 0,057 & 0,038 & 0,019 & 0,005 & 0,008 & 0,027 & 0,002 & 0,021 & 0,011 \\
\hline Van & 0,069 & 0,084 & 0,038 & 0,075 & 0,069 & 0,023 & 0,008 & 0,011 & 0,017 & 0,034 & 0,019 & 0,005 \\
\hline
\end{tabular}

Step 4: Negative and ideal solution values are calculated and they are given in table 24.

Table 24. Negative and positive ideal solution values.

\begin{tabular}{|l|l|l|l|}
\hline & $\mathrm{S}_{\mathrm{i}}^{*}$ & $\mathrm{~S}_{\mathrm{i}}^{-}$ & $\mathrm{C}^{*}{ }_{\mathrm{i}}$ \\
\hline Burdur & 0,039550951 & 0,0829841 & 0,6772273 \\
\hline Antalya & 0,109947039 & 0,0354335 & 0,2437295 \\
\hline Karaman & 0,039566991 & 0,0837497 & 0,6791432 \\
\hline Konya & 0,048871274 & 0,095972 & 0,662592 \\
\hline Mersin & 0,036273357 & 0,0879866 & 0,7080848 \\
\hline Van & 0,046534608 & 0,087803 & 0,6535996 \\
\hline
\end{tabular}

Step 5: The alternatives are ordered according to their ideal solution relative affinity $(\mathrm{Ci} *)$ values as shown in table 25 .

Table 25. Ranking of Alternatives.

\begin{tabular}{|l|l|}
\hline Order & Alternative \\
\hline 1. & Mersin \\
\hline 2. & Karaman \\
\hline 3. & Burdur \\
\hline 4. & Konya \\
\hline 5. & Van \\
\hline 6. & Antalya \\
\hline
\end{tabular}

\section{Results and Discussion}

In this study, the weights of the criteria that affect location of solar power plant are found with the AHP method. In the order of the weights of the main criterion, the technical criteria are ranked first with 46,3 percent, the economic criteria second with 33,2 percent, the third with 13,7 percent geographical criteria and the social criteria with the last ranking with 6,8 percent. Among the sub criteria of the technical criteria, 44,4 percent has the highest weight of solar radiation, followed by 35,7 percent with sunshine duration, and finally 19,9 percent with the amount of energy. The highest criterion among the sub-criteria under economic criteria is in the land costs with a weight 57,3 percent, then 29,7 percent with the sub-criteria of regional incentive application, and then with the sub-criteria of 13,0 percent, in the transformer tariff area. Among the sub-criteria of the geographical criteria main criteria, with the rainfall amount is 46,5 percent is first, with 26,1 snowfall day is the second, with 15,8 percent erosion risk is third and with 11,6 percent is earthquake risk fourth. Among the sub-criteria under the social criteria, 69,1 percent unemployment is in the first place and 30,9 percent workforce in the second place. When TOPSIS method is 
applied with these criteria weights, it is shown that Mersin is the best alternative for solar power plant in Turkey. Mersin is followed by Karaman, Burdur, Konya, Van, Antalya as shown in figure 2.

In the study of Özdemir et al., Van, Malatya, İstanbul, Kayseri, Antalya, Konya, Aksaray, Kocaeli, Burdur, Nevşehir, Adana, Denizli, Sinop are considered as alternatives [1]. Konya is selected as the best alternative for solar power plant with criteria of electricity production capacity, land square meter unit prices, the possibility of not having a terrorist attack, seismicity, the proximity to the solar energy by using AHP and VIKOR methods. Their study and this study are different in terms of criteria. For this study, Konya is forth alternative. In the study of Akkaş et al., Aksaray, Konya, Karaman, Nevsehir, Nigde are taken as alternatives [2]. AHP, TOPSIS, ELECTRE and VIKOR applied for this study and the most suitable for all methods Karaman is selected. Karaman is the ranked as second alternative in this study.

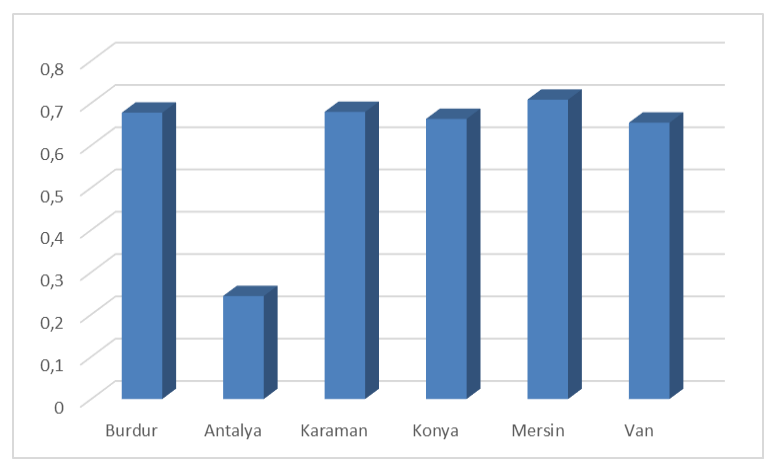

Figure 2. Result Graph.

\section{Conclusions}

In this study, an approach consisting of a combination of AHP and TOPSIS methods, which city is the most suitable for solar plant installation, is decided and alternatives are ranked. Criteria weights are found with AHP, and ranking is made with the TOPSIS. When this hybrid method is applied to the problem, alternatives are ranked as Mersin, Karaman, Burdur, Konya, Van, Antalya, respectively. Mersin is determined as the best city in among alternatives for solar power plant according to this study.

\section{Acknowledgement}

In this study, assistance is received from experts and engineers in the Directorate General of Renewable Energy under the Ministry of Energy and Natural Resources. Criterion weights are based on the scoring of these experts. For the TOPSIS application score, the data from the official sites of the institutions written full in the references are used.

\section{References}

1. Özdemir, B, Özcan, B, Aladağ, Z, Güneș enerjisi santrali kuruluş yerinin AHS ve VIKOR yöntemlerine dayalı bütünleșik yaklașım ile değerlendirilmesi, Erciyes University Journal of Science, 2017, 33(2), $16-34$

2. Akkaș, Ö. A, Erten, M. Y, Cam, E, İnanç, N, Optimal site selection for a solar power plant in the Central Anatolian Region of Turkey, International Journal of Photo energy, 2017, 1-13.

3. Sindhu, S, Nehra, V, Luthra, S, Investigation of feasibility study of solar farms deployment using hybrid AHP-TOPSIS analysis: Case study of India, Renewable and Sustainable Energy Reviews, 2017, 73, 496-511.

4. Lozano, S. J. M, Cascales, G. M. S, Lamata, M. T, Comparative TOPSIS-ELECTRE TRI methods for optimal sites for photovoltaic solar farms: Case study in Spain, Journal of Cleaner Production, 2016, 127, 387-398.

5. Beltran, P. A, Gonzalez, F. C, Ferrando, J. P. P, Rubia, A. P, An AHP/ANP based multi-criteria decision approach for the selection of solar thermal power plant investment projects, Energy, 2014, 66(2014), 222-238.

6. Wu, Y, Geng, S, Multi-criteria decision making on selection of solarwind hybrid power station location: A case of China, Energy Conversion and Management, 2014, 81, 527-533.

7. Garni, H. Z. A, Awasthi, A, Solar PV power plant site selection using GIS-AHP based approach with application in Saudi Arabia, Applied Energy, 2017, 206, 1225-1240.

8. Saaty, R. W, The analytic hierarchy process what it is and how it is used, Mathl Modelling, 1987, 9(3-5), 161-176.

9. Yurdakul, M, İç, Y.T, Türk otomotiv firmalarının performans ölçümü ve analizine yönelik TOPSİS yöntemini kullanan bir örnek çalışma, Gazi University Journal of Engineering and Architecture, 2003, 18(1), $1-18$.

10. Wang, Y, Elhag, T. M. S, Fuzzy TOPSIS method based on alpha level sets with an application to bridge risk assessment, Expert Systems with Applications, 2006, 31, 309-319.

11. Koçak, D, Coğurcu, Y. E, Network modeli ile ağ analizi için çok kriterli karar verme yöntemleriyle karşilaştirmali çözüm, Gazi Journal of Economics and Business, 2015, 1-42.

12. Monjezi, M, Dehghani, H, Singh, T. N, Sayadi, A. R, Gholinejad, A, Application of TOPSIS method for selecting the most appropriate blast design, Arab J Geosci, 2012, 5, 95-101.

13. Elektrik Piyasası Kanunu. http://www.epdk.gov.tr, (accessed 18.03.2018).

14. T.C. Ekonomi Bakanlığı, Yatırım teşvik sistemi. https://www.ekonomi.gov.tr/, (accessed 18.03.2018).

15. Emlak-Arsa Fiyatları. https://intvd.gib.gov.tr/2014_Emlak_Arsa/, (accessed 05.06.2018).

16. Türkiye Yenilenebilir Enerji Genel Müdürlüğü, Güneş. http://www.yegm.gov.tr/yenilenebilir/gunes.aspx, (accessed 18.03.2018).

17. Meteoroloji Genel Müdürlüğü, İllerimize ait genel istatistiki veriler. https://www.mgm.gov.tr/veridegerlendirme/il-ve-ilceleristatistik.aspx, (accessed 18.03.2018).

18. Türkiye Deprem Riski Haritası. https://deprem.afad.gov.tr/deprembolgeleri-haritasi, (accessed 18.03.2018).

19. Türkiye Erozyon Haritası http://www.cem.gov.tr/erozyon/AnaSayfa/ulusal_izleme_sistemlerimiz.aspx?sflang=tr, (accessed 18.03.2018)

20. İşü̈cü İstatistikleri. http://www.tuik.gov.tr/PreHaberBultenleri.do?id=2157, (accessed: 05.06.2018) 